\title{
Navigating the molecular diagnostic patent landscape
}

\section{DIANNE NICOL}

Published in (2008) 18 Expert Opinion on Therapeutic Patents 461-472

PhD (Biology, Dalhousie University, Canada), LLM (UTas)

\author{
Associate Professor \\ Centre for Law and Genetics \\ Law Faculty \\ University of Tasmania \\ Private Bag 89 \\ Hobart \\ Tas 7001
}

Email: $\quad$ Dianne.Nicol@utas.edu.au 


\section{Abstract \\ Background}

The molecular diagnostic patent landscape mostly comprises patents claiming rights over genes and other research tools. Many such patents have been granted, and many more await examination.

\section{Objective}

To explore the issue of whether such patents are leading to adverse socio-economic consequences by stifling innovation and access.

\section{Method}

This article begins with an examination of some key patents in the molecular diagnostic landscape and key aspects of their legality. Evidence of detrimental impact is then examined, using empirical studies conducted by the author in Australia and other researchers in other jurisdictions. Finally expert opinion is provided on the current impact and future challenges of patenting for the molecular diagnostic industry.

\section{Conclusion}

While enforcement of relevant patents against public-sector organizations appears to be somewhat less frequently encountered than might be expected, private organizations are likely to be exposed to far more such actions. It is argued that these organizations should consider more cooperative licensing strategies, outside the more traditional exclusive rights model.

Keywords: BRCA1, clearing house, gene patents, intron sequence analysis, molecular diagnostics, molecular diagnostic industry, ordre public or morality, patent pooling. 


\section{Introduction}

The number of molecular diagnostic tests for genetic diseases continues to increase. It was recently reported that, in a five-and-a-half-month period between late 2007 and early 2008 , the rate of increase in the number of diseases for which genetic tests are available was $8.4 \%$, bringing the total number of available tests to 1,236 [1]. In addition, developments in testing for variation in single nucleotide polymorphisms (SNPs) are opening up whole new fields like pharmacogenetics and pharmacogenomics [2].

Concomitant with this steady increase in number and types of tests, the molecular diagnostic patent landscape is inexorably becoming more and more cluttered. Navigating this patent landscape is a highly complex endeavour. If it were necessary for every clinical molecular diagnostic laboratory to work its way through the clutter of patents for every genetic test it performed, the delivery of testing services would, in all likelihood, be significantly delayed and costs would escalate. Similar concerns apply for research carried out in the molecular diagnostic space. The task of searching for relevant patents and interpreting claims is complex enough of itself. If negotiations then have to be entered into for use of products and processes within the scope of the claims, costs and timeframes would be further extended. If patent holders refuse to license or only license on restrictive terms then clinics may cease offering certain testing services and researchers may abandon research projects (the extent to which these eventualities have actually arisen in practice will be examined later in this article). 
How is it, then, that the number of molecular diagnostic tests continues to increase and research continues to be undertaken? Is it really the case that patents are leading to adverse socio-economic consequences by stifling innovation and access in this area? This paper explores these issues in five parts. First a brief overview of the molecular diagnostic patent landscape is undertaken. Key aspects of the legality of such patents are then considered. Particular attention will be paid to the recent decision of the European Patent Office (EPO) in a case considering the legality of one of the patents relating to the BRCA1 genetic test for susceptibility to hereditary breast and ovarian cancer [3]. The refusal by the US Supreme Court to hear a case relating to the patentability of a method for measuring blood homocysteine levels, will also be considered, because that case has reopened debate as to the legality of patents relating to products of nature in that jurisdiction [4]. Evidence of detrimental impact is then examined. Finally expert opinion is provided on the current impact and future challenges of patenting on the molecular diagnostic industry and strategies for navigating around some of these challenges.

\section{Patents in the molecular diagnostic landscape}

\subsection{Types of patents in the molecular diagnostic landscape}

The most prevalent types of patents in the molecular diagnostic landscape fall under the generic rubric of 'gene patents'. A 2005 study identified 4,270 human gene patents and concluded that patent claims existed for nearly 20 per cent of all human genes, with some genes featuring in up to 20 separate patents [5]. Yet what does and does not constitute a

gene patent is far from clear [6]. Gene patent claims are highly variable [7], ranging 
from: whole gene sequences to partial sequences; isolated corollaries of naturally occurring sequences to recombinant sequences, that lack the non-coding regions (introns) of the naturally occurring sequences; entire protein-coding sequences to hybridisable probes, regulatory regions and fragments of unknown function; wild-type sequences to disease-related mutations and other polymorphisms that do not necessarily affect function [6]. Claims can be specific to the identified nucleotide sequence, or broad enough to cover some or all of the possible variants that code for a particular polypeptide sequence, or, even more broadly, all of the nucleotide variants that code for all of the functional variants of a particular polypeptide sequence. Vectors, cell lines and host cells are also likely to be claimed. Products and processes can be claimed. Claims can be 'comprising' (including any subject matter that uses the disclosed sequence, even where those uses have not been disclosed) or 'consisting of' (restricted to the sequence as claimed) [8], [9]. This last aspect of gene patenting is one of the most controversial. Indeed, debate about the legality of gene patents crystallized in the early 1990s when multiple applications were filed by the US National Institutes of Health for 'comprising' patent claims relating to gene fragments of unknown function (otherwise known as expressed sequence tags or ESTs) [10].

In addition to this amalgam of subject matter that might come within the ubiquitous 'gene patent' badge, research tool patents also loom large in the molecular diagnostic landscape. Research tools are the technological developments that enable particular lines of research to be pursued, that, of themselves, may have no direct therapeutic or 
diagnostic application [7], [11]. Gene sequence information itself can be a research tool, since it, like other research tools, can guide future research [7].

In this article, the term 'gene and related patents' is used to describe all relevant patents in the molecular diagnostic landscape. Mapping this landscape in its entirety is an arduous process, requiring the development of search strategies for identifying relevant patents and templates for classifying claims. Research groups in the US and Europe have been developing such strategies and templates for some years [5], [12], [13], [14], [15], but give the complexity of the landscape, progress is slow and the techniques developed by different groups do not necessarily produce consistent results. While is would be impossible to survey the entirety of this landscape in an article of this scope, some of key patents are briefly summarised in this section to provide some idea of the general contours of the landscape. As most of these patents were first filed in the US, US patent details are provided.

\subsection{BRCA1}

Perhaps the most notorious gene patents in terms of alleged impact on molecular diagnostics are those associated with BRCA testing [16], [17]. Myriad Genetics, Inc was formed in the early 1990s as a spin off from the University of Utah and focused much of its early research effort on discovery of the genes associated with hereditary breast and ovarian cancers, at the same time as other researchers were turning their attention to this task [14]. In 1996 the University filed patents claiming rights to the BRCA1 gene and various mutations and gave Myriad exclusive licences. One prominent example is 
US5753441, entitled '170-linked breast and ovarian cancer susceptibility gene', filed on 5 January 1996 and granted on 19 May 1998 [18]. Through this and other patents granted in the US and other jurisdictions, Myriad acquired broad rights over a range of mutant BRCA1 gene sequences and their use in diagnosis and prognosis of breast, ovarian and other cancers, therapies and drugs. The patents include claims to a whole range of methods for identifying, screening and detecting mutant sequences, nucleic acid probes hybridizable to the gene sequences, cloning vectors, expression systems and recombinant host cells. Other patents relate to BRCA2, a second gene connected to hereditary breast and ovarian cancer.

\subsection{Hungtington's disease}

The task of characterising the gene associated with the development of Huntington's disease was a long and frustrating process taking ten years from the time when the gene was first located on chromosome 4 in 1983 by scientists working in the Massachusetts General Hospital [19]. As with BRCA, various patents relating to testing for Huntington's disease [20] and the Huntington's disease gene [21] were filed in the US and other jurisdictions.

\subsection{Recombinant DNA technology}

Recombinant DNA technology is a classic example of a research tool. There are no alternatives to this technology and it is essential to all research in molecular biology [22]. The technology was developed by Herbert Boyer and Stanley Cohen at Stanford University and the University of California in the early 1970s. In an unusual step for the 
time, patents were filed by Stanford and the University of California and granted in the 1980s [23], [24].

\subsection{Polymerase chain reaction and taq polymerase}

The polymerase chain reaction (PCR) enables specific and rapid amplification of existing DNA or RNA sequences in a test sample. Part of the process of PCR involves separating double stranded DNA using high temperatures. Taq polymerase is the enzyme used in the amplification, useful for its heat-resistant properties. Like recombinant DNA technology, it is a fundamental research tool in molecular biology. This technology was first developed by Kary Mullis at Cetus Corp. Various patents were filed and granted and subsequently assigned to F Hoffmann-La Roche AG [25], [26], [27].

\subsection{Intron sequence analysis}

Genetic Technologies Ltd (GTG) is a small Australian biotechnology company that owns a number of patents relating to intron sequence analysis. These patents are extremely broad, encompassing much of the current technology that utilises non-coding regions in human and non-human genomes as molecular markers in both the research and clinical contexts. Essentially, they claim a method of using non-coding regions of DNA to predict mutations in active coding regions. GTG has been successful in obtaining patents in the US and other countries [28], [29], [30]. 


\section{Legality of patents in the molecular diagnostic landscape}

\subsection{Application of the patent and disclosure criteria}

Although many gene and related patents have been granted and many more await examination, their legality remains contentious. Traditionally, discoveries and products of nature have not been considered to fulfil the subject matter requirement because the essence of an invention is that knowledge and ingenuity are used to produce something new and useful. Although it is still widely accepted by patent offices and courts that products of nature as such are not patentable, isolation and purification of component parts of living organisms will take them outside the realm of this exclusion. Essentially, isolated genes and other nucleotide and polypeptide sequences are treated in law in the same way as other chemical compounds. Hence, they are patentable provided that they fulfil the technical patent requirements of novelty, inventive step, and industrial applicability [31].

Whilst the isolation and characterisation of a gene outside of its natural environment might be sufficient to satisfy the novelty requirement, because prior to this the gene sequence was not publicly available, the situation with regard to fulfilment of the inventive step and industrial applicability requirements is more complex. The extent to which it is permissible for claims to extend beyond the boundaries of disclosure adds a further layer of complexity. There has been some judicial scrutiny and policy debate in relation to each of these criteria [31]. 
For inventive step, arguably, the techniques used to isolate and characterise genes are now so routine that little inventive ingenuity is required. However, in the US, the inventive step requirement has been interpreted liberally, focusing on the invention itself, not the techniques for producing it. This means that the question is whether the gene sequence is obvious, not whether the method used to obtain it was obvious to try. The US courts have accepted that the redundancy of the genetic code means that until the claimed molecules are actually isolated and purified it would have been highly unlikely that a person skilled in the area could have contemplated what was obtained [32], [33]. In Europe, in contrast, the focus is on whether the technique used to isolate the gene was 'obvious to try' [7]. There have been calls for a similar stringent test to be adopted in the US, but at present the more lenient test continues to be determinative of the inventive step requirement [14].

Industrial applicability requires something more than mere disclosure of a gene sequence, because sequence information does not of itself provide much in the way of commercial utility. In the US, where industrial applicability is determined by the utility requirement, applicants must show specific, substantial and credible utility of the claimed invention [34]. This requirement may be met for gene patents if the protein-coding function of the sequence is disclosed. Gene fragments in the form of expressed sequence tags, with limited function as research probes, will rarely be patentable [35]. However, single nucleotide polymorphisms, which can be used to detect genetic variation across populations, are more likely to satisfy the utility requirement if they are used in forensic or pharmacogenetic testing [9]. 


\subsection{The European BRCA litigation}

The above analysis of patent requirements illustrates that there has been a willingness to interpret the patent criteria in such a way that they do not impose insuperable hurdles. An opportunity for judicial re-examination the legality of gene patents was provided in opposition proceedings relating to certain of the European BRCA1 patents: EP699754 (claiming methods of diagnosis) [36], EP705903 (claiming various mutations of the BRCA1 gene) [37] and EP705902 (claiming the BRCA1 gene and protein and therapeutic applications) [38]. As a result of these proceedings EP688754 was struck down [39] and some of the claims in the other patents were declared invalid [40], [41]. The main problem with the patents was that the specified DNA sequences in the patents as granted were not precisely the same as those disclosed in the original applications and hence the original priority date could not be relied upon for determining novelty and inventive step. The broad claims were revoked by the Opposition Division and much narrower claims relating to hybridizable probes, cloning vectors and host cells were all that remained. Although these decisions provided beneficial outcomes for providers of BRCA1 testing services in Europe [42], they did little to clarify the law in this area since they primarily rested on technical issues arising during the process of prosecuting the patent applications.

The EPO Board of Appeal (the Board) were given the opportunity to delve more broadly into the legality of gene patents in an appeal from the opposition to EP705902 in University of Utah Research Foundation/ Breast and Ovarian Cancer (the BRCA1 
appeal) [3]. Appeals came from the University of Utah (assignee of the patent - appellant 1) and one of the original opponents (Sozialdemokratische Partei der Schweiz - appellant 2). Appellant 1 requested that the decision revoking the main patent claims should be reconsidered. Appellant 2 sought to have the opposition proceedings upheld (allowing the patent in limited amended form) or the patent revoked. At the outset, the Board gave short shrift to appellant 1's argument that it did not matter that the original sequence and the claimed sequence were not precisely the same. For the Board, the original and claimed sequences were not 'the same invention' [3 - para 29]. Appellant 1's argument that the deviations did not affect function was not accepted.

The Board then considered the claims allowed by the Opposition Division, concluding that, as they were derived from the original application, the early priority date could be relied on. The interesting part of the Board's decision follows on from this. The Board examined whether the claims satisfied the subject matter requirement and concluded that because they relate to nucleic acid probes comprising partial DNA sequences of the human BRCA1 gene, they are isolated elements of the human body and hence are inventions not discoveries [3 - para 45].

Appellant 2 argued that the claims should be excluded under Article 53(a) of the European Patent Convention (EPC) [43], which provides that:

European patents shall not be granted in respect of:

(a) inventions the publication or exploitation of which would be contrary to 'ordre public' or morality ...; 
A number of grounds were raised in support of this argument. First, donation of human cells had been critical in identifying BRCA1 and donors had not given informed consent to commercial exploitation of the research results [3 - para 47]. Appellant 2 used recital 26 of the European Biotechnology Directive [44] to support their argument. The purpose of this Directive is to provide assistance in interpreting the EPC for biotechnology patents. Recital 26 provides that when an invention is based on biological material of human origin the donor must have had the opportunity for expressing informed consent in accordance with national law. In the BRCA1 appeal, the Board noted that despite the presence of Recital 26, there is nothing in the EPC framework mandating verification of consent and that the absence of such provisions is not contrary to human rights obligations, such as the right to self-determination.

The second ground raised by appellant 2 was that socio-economic consequences of exploiting the patent (including increased costs and influence on diagnostics and research) should be considered. The Board did not accept this argument either, emphasising that Article 53(a) relates to exploitation of the invention, not the patent. It was noted that the ordre public or morality consequences of the exploitation of the patent alleged by appellant 2 were the result of the exclusionary nature of the rights granted by a patent: 'the right to stop competitors from using the invention' and that such consequences would apply to the exploitation of any patent [3 - para 53].

Finally in relation to Article 53(a) the Board noted that no arguments or evidence were led by appellant 2 as to whether exploitation of the invention itself would be contrary to 
ordre public or morality [3 - pare 56]. Based on prior case law, it is most unlikely that such arguments would have been successful in any event. For example, in Howard Florey/Relaxin, concerning the molecular cloning and characterisation of a gene coding for human relaxin, the Opposition Division held that Article 53(a) should only be invoked in rare and extreme cases, to ensure that patents are not granted for inventions that would universally be regarded as outrageous [45]. The invention at issue in that matter was held not to be such a case. As a consequence of the Board's decision in the BRCA1 appeal, the Opposition Division decision in Howard Florey/Relaxin and other European case law, it seems that there is little or no scope for using socio-economic or other ordre public or morality arguments to invalidate a gene or related patent.

Appellant 2 in the BRCA1 appeal raised various other arguments based on industrial applicability, priority and inventive step. While it is not necessary to discuss these in detail, two relevant points warrant mention. First, the Board concluded that use of the claimed invention for diagnosis of cancer is sufficient to satisfy the industrial applicability requirement [3 - para 67]. Secondly, the Board added some clarification to the European interpretation of the inventive step requirement. Recalling that in Europe the inquiry is whether the steps undertaken by the inventor were obvious to try, the question is 'whether a skilled person, having consulted the relevant prior art, would have readily undertaken the task performed by the inventor and would have had a reasonable expectation of success'. In discussing the requirement for a reasonable expectation of success, the Board stated that this requires more than a mere 'hope to succeed'. What is required is 'the ability to predict, based on the particular technical circumstance, a 
successful conclusion to the project within acceptable time limits' [3 - para 77]. This will be decided on a case-by-case basis. In the circumstances of this case, the claims accepted by the Opposition Division were held by the Board to satisfy the inventive step threshold.

What is important from this and other relevant European decisions is that claims to nucleic acid probes (and, indeed, to full gene and polypeptide sequences) do not per se fail to satisfy the inventive step and industrial applicability grounds. Nor do they fail to satisfy the subject matter requirement. Given that the subject matter inquiry in Europe is

more searching than in other jurisdictions and that the inventive step requirement tends to be more stringently applied, many more patents in the molecular diagnostic landscape are likely to be valid. Admittedly, the opponents to the BRCA1 patents in Europe succeeded in striking out key patent claims, but this was based on technical legal issues specific to that case. Other claims may also be struck out in future, but challenges are expensive and success is difficult to predict.

\subsection{The US LabCorp $v$ Metabolite litigation}

The LabCorp $v$ Metabolite litigation relates to US patent 4940658 [46], claim 13 of which is for assays for measuring levels of homocysteine in body fluids of warm-blooded animals and correlating elevated levels with deficiencies in the vitamins cobalamin and folate. Although this patent is not within the molecular diagnostics landscape as such, the outcomes of the litigation have been mooted as having significant implications for that landscape [47]. 
The focus of the litigation was on whether LabCorp, by encouraging doctors to order diagnostic tests for measuring homocysteine, induced them to infringe the patent. At trial [48] and on appeal [49], the courts held that the patent claim was valid and that LabCorp was liable for two reasons. First, any competent doctor who ordered tests for homocysteine levels would correlate test results with the presence or absence of a vitamin deficiency, and would thus be a direct infringer. Secondly, because LabCorp published articles that urged doctors to conduct the relevant tests and to make a determination on vitamin deficiency levels based upon the test results, this was enough for it to have induced infringement. The US Supreme Court initially agreed to hear a further appeal on these matters (through a so-called writ of certiorari) [4], but subsequently the majority of the court dismissed the action on the basis that it was improvidently decided, without delving further into the legality of claim 13 [50].

In a strong dissenting judgment, Justice Breyer, joined by Justice Stevens and Justice Souter pointed to the fact that the correlation between homocysteine and vitamin deficiency was a natural phenomenon. It is well established in patent law that to be valid, claims to natural phenomena must include some sort of practical application. Metabolite argued that claim 13 gave the correlation between homocysteine and vitamin deficiency practical application because it claimed a 'process' for detecting vitamin deficiency, with discrete testing and correlating steps. This argument did not convince the minority of the Court, who saw the process as 'no more than an instruction to read some numbers in light of medical knowledge'. On this basis claim 13 should have been declared invalid and not infringed. 
It has been argued that genetic testing involves the same sort of correlation exercise between a patient's DNA sequence and a reference sequence [47]. It has also been suggested that, based on the minority judgment of the US Supreme Court and comments made by another of the Supreme Court justices when the case was being heard, the Court as a whole may well have found that claim 13 was invalid if it had been given the opportunity to do so [47]. As a consequence, this case has re-ignited the debate about the patentability of claims relating to genetic testing.

We might debate at length the rights and wrongs of legislation that is silent on the issue of patenting of genes and judicial decisions that interpret the legislation in such a way as to allow such patents. Indeed, much ink has been spilled on this issue. But the facts are that such patents have been issued and sanctioned by the courts. Legislation could be amended now to halt the surge of new gene patents, if that is deemed an appropriate policy direction, but the molecular diagnostic landscape is already cluttered with patents and the legal landscape is cluttered with precedents upholding their legality. The US Supreme Court may one day be given the opportunity to pronounce on these issues, but this may take some years. The real question that needs to be asked now is whether there is a way through this clutter to avoid the types of deleterious socio-economic consequences mooted by the opponents to the BRCA1 patents. 


\section{Evidence of the impact of patents in the molecular diagnostic landscape}

\subsection{Impact of patents on clinical diagnostic services and molecular diagnostic research}

We have seen that gene and related patents are abundant and that to date courts and patent offices have not found that there is anything inherently unpatentable about them. Depending on how these patents are used, deleterious socio-economic consequences could result. Although the justification for patents is that they promote innovation, there is growing concern that gene and related patents may be used in ways that could have a significant negative impact on molecular diagnostics in both the clinical and research contexts [51].

Subject to any limitations imposed by law, the grant of gene and related patents entitles patent holders to enforce their patents against others, and to chose whether or not to license others to use those patents, to determine the conditions of use, and even, if they so chose, to ignore infringing actions. Where patented products are bought off the shelf, the product price includes a component for recovery of research costs. In such circumstances, patent costs are just one component of budget for doing research or testing.

Whilst some laboratories may choose to purchase commercial products, if they are easy and cheaper to make in-house this may be the preferred option. In such circumstances, the patent holder may demand that the laboratory enters into a licensing agreement. The problem with this is that licences give much greater scope for collecting fees and 
imposing other restrictions beyond the simple allocation of royalties out of the profits from product sales. Upfront, annual and milestone fees may be charged, as well as a percentage of royalties on downstream product sales. Limits might be place on the quantum of in-house use of the patented technology, or it might be prohibited entirely. In the research context, fees are also likely to be the major hurdle, but additional restrictions may also be imposed on publication, collaborations, sharing of materials and future commercialisation.

For gene and related patents, it will often be the case that there are no products as such against which royalties can be collected and hence enforcement is by way of individually-negotiated or standard term licences. As an example, Myriad has been actively enforcing its patent rights against laboratories offering BRCA tests in a number of countries, requiring that samples are sent to Myriad's own laboratories in Utah for testing [52]. In contrast, patent rights associated with the Huntington's disease gene have not been asserted and licences have not been issued for financial gain [14].

As a general rule patented research tools tend to be non-exclusively licensed [53], often for small fees. This is not meant to suggest that all research tools are licensed in this way. Examples of more restrictive licensing practices have been noted in the literature for a number of years [22], [54], [55]. Yet non-exclusive licensing of research tools can be highly beneficial financially for the patent holder, at the same time causing minimal imposts for licensees. This strategy was remarkably lucrative for the owners of the recombinant DNA patents, with returns of US $\$ 139$ million by 1995 [22]. PCR has also 
been non-exclusively licensed and while it would appear that licence terms are not particularly onerous, there has been more criticism of the cost of taq polymerase.

GTG has also successfully negotiated non-exclusive licensing arrangements with universities, commercial entities and providers of molecular diagnostic services in various jurisdictions, allowing use of its patented intron sequence analysis research tool [56]. While non-commercial organisations are offered research licences for nominal, oneoff fees, commercial licensees pay significant fees for past infringement and future use. For example, in 2003 Myriad itself agreed to pay an upfront fee of US\$1 million for a non-exclusive licence to GTG's patents, as well as annual licence fees and other nonmonetary consideration. Since then, GTG has continued to actively pursue its licensing strategy, reporting that in 2007 alone it earned \$11.3 million in license fees [57]. In the clinical context, GTG settled a dispute with the Auckland District Health Board in New Zealand relating to alleged infringement of its patents in diagnostic testing on undisclosed terms [58]. Despite fears that other public diagnostic service providers might be targeted [56], no other relevant licensing agreements have been disclosed on GTG's website to date [58]. What this account of GTG's actions suggests is that just because a patent is non-exclusively licensed, it doesn't necessarily follow that the impact on potential licensees is insignificant in monetary terms.

Both of the Myriad and GTG scenarios are often presented as evidence of the potential for gene and related patents to have detrimental socio-economic consequences [59]. There is some evidence of more widespread enforcement of gene patents in clinical 
molecular diagnostic testing in the US. Research published in 2003 reports that a number of gene patent and licence holders were actively enforcing their patents against providers of genetic tests by refusing to license or imposing restrictive terms in licences [51], [60]. These actions reportedly led to a number of test providers ceasing to perform genetic tests they had previously offered and to a number of others deciding not to develop or perform a test because of the patent considerations. In total, 22 patents were identified as being actively enforced, affecting 12 genetic tests, some of which related to common genetic disorders, including haemchromatosis, Fragile $\mathrm{X}$ syndrome, Duchenne muscular dystrophy and Huntington's disease. Others related to more complex disorders such as Alzheimer's disease and hereditary breast and ovarian cancer.

In contrast, a similar published study by the author in Australia [61] found little evidence of enforcement of patents against public testing laboratories and the results of yet to be published studies in New Zealand [62] [personal communication Aphra Green] and the UK [personal communication Naomi Hawkins] appear to be closely aligned with those in Australia. There is also a dearth of commentary in the academic and popular media about specific patent enforcement actions in relation to clinical molecular diagnostic testing outside the US, save for the Myriad and GTG cases discussed above.

In the research context, a number of strategies have been used to attempt to measure the impact of gene and related patents. For example, one research group used citations in peer-reviewed journals [63]. They identified research that had been both published and patented and measured the number of citations pre- and post-patent grant. They found 
that citations do significantly decrease post grant, but only in a modest way. Whilst their results suggest that patents appear to create some restrictions on subsequent research, the impact is not excessively detrimental. Other empirical research involving questionnaires and interviews with public sector researchers suggests that in their view gene and related patents rarely impede research programs [61], [64].

\subsection{The legal landscape}

The evidence presented above suggests that widespread enforcement of gene and related patents against molecular diagnostic testing laboratories and public research organizations has not emerged to date, aside from some isolated examples and some more worrying trends from the US clinical molecular diagnostic sector. However, concern continues to be expressed within these sectors about the impact of patents on research and on the provision of tests to end-users [65], [66], [67]. Law reform agencies in various jurisdictions have scrutinised this area on some detail, and have come to common conclusions as to the way forward [68], [69], [70]. It is widely accepted that research relating to patented inventions should be exempt from patent infringement actions, but only to the extent that it involves testing the validity of the claimed invention, or understanding how the invention works, or exploring how to make improvements to the invention. One difficulty in this area is that the law is uncertain because in some jurisdictions patent legislation includes express experimental use provisions (eg, the UK), in others there is a limited common law exclusion (eg, the US) and in others still the legislation is silent and there is no case law directly on point (eg, Australia) [71]. A 
further difficulty is that exemptions of this nature do not protect use of patented research tools, even when that use is for research purposes [14], [68].

Patent legislation often includes other provisions allowing use of the patented invention without the permission of the patent owner, which may be triggered when the patent holder fails to provide sufficient pubic benefit from the patent grant. For example, a compulsory licence is a court or administrative order requiring the patent holder to allow others to work the invention. Government use is use of the invention by the government for the purposes of the state without having to obtain permission from the patent owner. In Australia, the Australian Law Reform Commission has suggested that the provision of public health services, including diagnostic testing, could fall within the concept of government use [69]. The circumstances in which compulsory licences and government use are allowed vary from country to country [69].

To date, the appropriate circumstances have not arisen for testing the capacity of the research exemption or the compulsory licensing or government use provisions to circumvent adverse socio-economic consequences of patent enforcement in the molecular diagnostic landscape. Such circumstances may arise in the future, but for now it would seem that public sector researchers and clinicians may not need to be overly concerned that they will be faced with a flood of patent enforcement demands, despite the complexity of the patent landscape. In effect, it seems that many patent holders might well be content to allow public footpaths to traverse their property in the molecular diagnostic landscape. This not to say that public organizations are entirely freed from the 
fetters of patent enforcement. The risk remains that from time to time individual patent holders might decide to aggressively pursue their patent rights against such organizations. Strategic decisions have to be made about how to respond at those times.

On the other hand, commercial entities cannot afford such complacency. One of the reasons why there is more evidence of patent enforcement against clinical molecular diagnostic laboratories in the US than elsewhere might well be because that jurisdiction tends to have a higher ratio of private to public laboratories [51], [56] (recognising that patent holders might also be strategically targeting testing facilities in that jurisdiction because of the higher volume of testing than elsewhere, and hence the greater opportunity for remuneration). Assessment of the impact of patents in the molecular diagnostic landscape requires scrutiny of the changing nature of the landscape, particularly focusing on the increasing commercialisation of this sector.

\subsection{Impact of patents on the molecular diagnostic industry}

The private sector has, for many years, been involved in the manufacture and sale of commercial test kits and other reagents that laboratories require for research and clinical diagnostic purposes. More recently, however, genetic testing itself has been developing into a potentially lucrative industry. Many companies specialise in providing genetic testing for specific disease traits, either directly to consumers or acting as intermediaries between consumers and testing facilities [72]. Others specialise in offering tests for the range of SNPs used to predict predisposition to cardiovascular disease, response to drug treatments and a whole range of other conditions that impact on lifestyle. The availability 
of such tests raises a host of scientific, legal, ethical and social concerns, ranging from the accuracy and validity of test results to the need for appropriate genetic counselling, the requirements for fully informed consent and the protection of privacy and confidentiality [73]. These considerations, together with difficulties in obtaining reimbursement for diagnostic testing and low profit margins tend to make this industry sector unattractive to investors [74].

The complexity of the molecular diagnostic patent landscape doubtless creates further investment disincentives [74]. Yet despite these uncertainties about the value and viability of the industry, it is recognised as offering important future benefits in terms of efficient and effective healthcare delivery [75]. For this reason alone, it is important to ensure that adverse socio-economic consequences of patenting of gene and related inventions are avoided to the greatest extent possible. But at the same time, the overarching purpose of the patent system should not be forgotten. Patents promote innovation by encouraging patent holders to commercially develop their inventions and to invest in further inventive activity. If too many limitations are imposed on these incentives then different kinds of adverse socio-economic consequences could result. In many countries, governments have fostered the development of indigenous biomedical industries at the interface between research and clinical practice through grants and other incentives [14], [69]. As patents are the only products for many of these industry participants [76], their survival and their ongoing involvement in research and development depends on their ability to maintain and license out those patents. The balance is a delicate one. 
The work of John Walsh and his colleagues in the US [55] suggests the biomedical industry as a whole is finding ways of working around perceived problems associated with gene and related patents, particularly the risks that broad patents and patent thickets will deter downstream innovation [77], [78]. Research in Australia and Europe supports the Walsh findings, consistently reporting that industry players are able to license out their own technology and license in the technology they need to secure freedom to operate [61], [79] [80], [81]. It seems that, for the most part, research tool patent holders license widely, and users engage in a number of strategies to ensure that their research and development programs can continue, including licensing-in, inventing around, litigating to challenge patent validity, moving offshore, or simply ignoring the patents that would otherwise block their research.

Despite this optimistic picture, molecular diagnostic companies do have to navigate through the increasingly complex patent landscape, and the associated challenges should not be trivialised. Companies involved in the development of microarray technology, which allows for multiple tests to be undertaken, are likely to face the greatest level of complexity. If such companies wish to ensure freedom to operate, they have to undertake onerous search obligations to ascertain which patents contain relevant claims and then enter into multiple licensing negotiations. The risks of royalty stacking and hold up by intransigent patent holders in such an environment are particularly high. It is not surprising that leaders in the field like Affymetrix rail against gene and related patents [82]. 


\section{Conclusion}

We have seen that the molecular diagnostic patent landscape is indeed highly complex, both in terms of numbers and types of patents, and it is safe to assume that if all such patents were enforced against researchers and clinicians there would be adverse socioeconomic consequences. However, it would be premature to end our discussion of the challenges in navigating the molecular diagnostic patent landscape at this point.

Realistically, it is not in the interest of any one patent holder to create a situation leading to industry collapse. For this reason alone, it is sensible for patent holders to take a pragmatic approach with regard to use of their patented inventions by non-commercial entities. Both research use and clinical use are more likely to enhance rather than stultify the development of the industry. Hence, currently it is not the norm for researchers and clinicians operating in the public sector to be exposed to aggressive patent enforcement actions, nor is such a norm likely to emerge in the near future (recognising that isolated instances of such enforcement actions probably will continue to occur). But a different response might be expected where users are primarily profit-driven. In such circumstances, patent holders are far less likely to be willing to forego patent licensing revenue. 


\section{Expert opinion}

Companies operating in the molecular diagnostic patent landscape are likely to face many challenges in the years ahead, including wasted expenditure associated with patent searches and licensing negotiations, together with potential risks associated with hold out by holders of foundational patents, insistence on restrictive licensing terms and royalty stacking resulting from patent thickets. The lack of clear legal solutions to the challenges associated with enforcement and use of gene and related patents is encouraging academic commentators, policy makers and the industry itself to explore other solutions. Top-down support has been expressed by leading national and international agencies for nonexclusive licensing of gene and related patents [69], [70], [83], [84], [85]. But this does not necessarily assist patent holders in the challenging task of identifying users of their technology to license out to. Nor does it assist users in identifying relevant patents and negotiating arrangements for licensing-in to ensure that they have freedom to operate.

It should be recognised that, at the very least, mechanisms need to be put in place to streamline licensing negotiations and agreements for the benefit of patent holders and users. For example, standard term, non-exclusive licences may often be adequate for licensing gene and research tool patents in molecular diagnostics. The molecular diagnostic industry may also benefit from the establishment of some type of collective rights arrangement. Patent pooling is one strategy that should be considered. A patent pool is an agreement between two or more patent holders to aggregate or pool their patents, particularly those deemed 'essential' to a given product. Since the 1850 s, patent 
pools have played a significant role internationally in bringing a range of products to the marketplace [86].

These types of private arrangements could ameliorate some of the problems arising from the proliferation of gene and related patents in the molecular diagnostic sector [87], [88], [89], although some doubt has been expressed as to whether there is sufficient incentive for patent holders to willingly enter into voluntary arrangements of this nature [79]. Nevertheless, patent pool-type arrangements are emerging in some biotechnology sectors, including a pool to collectively manage the patents relating to golden rice for diffusion to developing countries (golden rice has been genetically engineered to produce a precursor to vitamin A) [90], and proposed pools in relation to medicines for HIV/AIDS, pandemic influenza, malaria and the SARS virus [91]. These examples suggest that patent pools offer some promise in addressing the socio-economic costs associated with patenting and licensing in biotechnology. Some scepticism has been expressed about the usefulness of such pools in the present regulatory framework and industrial context of biotechnology, but there is more optimism about their potential role in the future [92].

The use of clearinghouse mechanisms should also be explored as a means of reducing the transaction costs in licensing gene and related patents in the molecular diagnostic sector. A clearinghouse might perform one or more of the following functions: facilitating the search for technology that is available for licensing or for free; smoothing the progress of negotiations; and monitoring or enforcing negotiated agreements [93]. Like patent pools, clearinghouses are already being established in some biotechnology sectors. For example, 
the Public Intellectual Property Resource for Agriculture (PIPRA) facilitates sharing of access to agricultural technologies by US-based public-sector agricultural research institutions. There has also been a proposal for the establishment of a royalty collection clearinghouse in diagnostics, modelled somewhat on the copyright collecting societies [94].

Other mechanisms like open source licensing also warrant some consideration [95]. There is unlikely to be one 'right' way forward for the molecular diagnostic sector, and these options should not be seen as mutually exclusive [96]. However, preliminary results from a survey currently being undertaken by the author in Australia and colleagues in Europe indicate that there is still a perception among many industry participants that there is no urgent need to explore these options. This research indicates that significant hurdles will need to be overcome before the majority of industry participants will willingly enter into such arrangements. These include complexity, expense, loss of exclusivity and inability to engage with all relevant parties. It is argued that at this stage of the development of the molecular diagnostic industry sector it is timely to explore and experiment with these industry-driven mechanisms. It may be that renewed uncertainty as to the legality of gene patents resulting from the actions of the US Supreme Court in the LabCorp $v$ Metabolite litigation will encourage industry participants to take a more cooperative approach. But in addition to this, policymakers also need to play a more active role in advising the industry about how these mechanisms might operate, and assisting with their design, set up and implementation, and, if necessary, providing incentives for their uptake, for the socio-economic benefit of society as a whole. This 
should be part of a broader policy discussion on patenting and licensing in molecular diagnostics, which should include all relevant players, as recently recommended by the European Society of Human Genetics [97].

\section{Bibliography}

1. Editorial. Genetic benefits at risk. Nature 2008; 451: 745-46

2. Ito RK and Demers LM. Pharmacogenomics and pharmacogenetics: future role of molecular diagnostics in clinical diagnostic laboratory. Clinical Chemistry 2004; 50: $1526-1527$

3. University of Utah Research Foundation/Breast and ovarian cancer. Case number T1213/05. Board of Appeals of the European Patent Office; 27 September 2007

4. Laboratory Corp of America v Metabolite Laboratories, Inc, 126 SCt 2921 (2006)

5. *Jensen $\mathrm{K}$ and Murray $\mathrm{F}$. Intellectual property landscape of the human genome. Science 2005; 301: 239-240

This article has been widely cited as evidence that gene patenting has extended beyond acceptable limits.

6. Holman CM. The impact of human gene patents on innovation and access: a survey of human gene patent litigation. University of Missouri - Kansas City Law Review in press. Electronic pre-publication copy available at http://ssrn.com/abstract=1090562 [Last accessed 19 April 2008]

7. Nuffield Council on Bioethics. The ethics of patenting DNA: a discussion paper. London: Nuffield Council on Bioethics, 2002

8. Goldstein JA and Golod E. Human gene patents. Academic Medicine 2002; 77: 1315 
9. Barton JH. Patents, genomics, research, and diagnostics. Academic Medicine 2002; 77: $1339-1347$

10. Eisenberg RS. Genes, patents and product development. Science 1992; 257: 903-908

11. Rai AK. Genome patents: a case study in patenting research tools. Academic Medicine 2002; 77: 1368-1372

12. Verbeure B, Matthijs G and van Overwalle G. Analysing DNA patents in relation with diagnostic genetic testing. European Journal of Human Genetics 2005; 1-8

13. Paradise J, Andrews L and Holbrook T. Patents on human genes: an analysis of scope and claims. Science 2005; 307: 1566-1567

14. National Research Council Committee on Intellectual Property Rights in Genomic and Protein Research and Innovation. Reaping the benefits of genomic and proteomic research: intellectual property rights, innovation and public health. Washington, DC: National Academies Press, 2006

15. Hopkins MM, Mahdi S, Thomas SM and Patel P. The patenting of human DNA: global trends in public and private sector activity (the PATGEN project). Sussex: Science Technology Policy Research Unit; Brighton, 2006

16. Williams-Jones B. History of a gene patent: tracing the development and application of commercial BRCA testing. Health Law Journal 2002; 10: 121-144

17. Rimmer M. Myriad Genetics: patent law and genetic testing. European Intellectual Property Review 2003; 25: 20-33

18. Skolnick MH, Goldgar GE, Miki Y, et al. 170-linked breast and ovarian cancer susceptibility gene. US5753441 (1998) 
19. Gusella, JF, Wexler NS, Conneally PM et al. A polymorphic DNA marker genetically linked to Huntington's disease. Nature 1983; 306: 234-238

20. Gusella, JF. Test for Huntington's disease. US4666828 (1987)

21. MacDonald ME, Ambrose CM, Duyao MP and Gusella JF. Huntingtin DNA, protein and uses thereof. US5686288 (1997)

22. National Research Council. Intellectual property rights and research tools in molecular biology. Summary of a workshop held at the National Academy of Sciences. Washington DC: National Academies Press, 1996

23. Cohen SN and Boyer HW. Process for producing biologically functional molecular chimeras. US4237224 (1980)

24. Cohen SN and Boyer HW. Biologically functional molecular chimeras. US4740470 (1988)

25. Mullis KB. Process for amplifying nucleic acid sequences. US4683202 (1987)

26. Mullis KB, Erlich HA, Arnheim N, et al. Process for amplifying, detecting, and/or 68. cloning nucleic acid sequences. US4800159 (1989)

27. Mullis KB, Erlich HA, Gelfand DH, et al. Process for amplifying, detecting, and/or cloning nucleic acid sequences using a thermostable enzyme. US4965188 (1990)

28. Simons MJ. Intron sequence analysis method for detection of adjacent and remote locus alleles as haplotypes. US5192659 (1993)

29. Simons MJ. Genomic mapping method by direct haplotyping using intron sequence analysis. US5851762 (1998)

30. Simons MJ. Intron sequence analysis method for detection of adjacent and remote locus alleles as haplotypes. US5612179 (1997) 
31. Nicol D. On the legality of gene patents. Melbourne University Law Review 2005; 29: $809-842$

32. Re Bell, 991 F 2d 781 (Fed Cir, 1993)

33. Re Deuel, 51 F 3d 1552 (Fed Cir, 1995)

34. United States Patent and Trademark Office. Utility Examination Guidelines. US Federal Register 66: 1092, 1095 (2001).

35. Re Fisher, 421 F 3d 1365 (Fed Cir, 2005)

36. Skolnick MH, Goldgar GE, Miki Y, et al. Method for diagnosing a predisposition for breast and ovarian cancer. EP699754 (1996)

37. Shattuck-Eidens DM and Simard J. In vivo mutations and polymorphisms in the 17qlinked breast and ovarian cancer susceptibility gene. EP705903 (1996)

38. Skolnick MH and Goldgar GE. 17q-Linked breast and ovarian cancer susceptibility gene. EP705902 (1996)

39. European Patent Office. 'Myriad/breast cancer' patent revoked after public hearing. Press release, 18 May 2004. Available at: http://www.epo.org/aboutus/press/releases/archive/2004.html [Last accessed 3 March 2008]

40. European Patent Office. Patent on breast and ovarian cancer susceptibility gene amended after public hearing. Press release, 21 January 2005. Available at: http://www.epo.org/about-us/press/releases/archive/2005.html [Last accessed 3 March 2008]

41. European Patent Office. European patent on mutations in breast and ovarian cancer susceptibility gene amended after public hearing. Press release, 25 January 2005. Available at: 
http://www.epo.org/about-us/press/releases/archive/2005.html [Last accessed 3 March 2008]

42. Vermij P. BRCA1 patent revisited. Nature Biotechnology 2005; 23: 277

43. Convention on the Grant of European Patents. Opened for signature 5 October 1973. United Nations Treaty Series 1065: 254 (entered into force 7 October 1977)

44. Directive 98/44/EC of the European Parliament and of the Council of 6 July 1998 on the Legal Protection of Biotechnological Inventions. Official Journal of the European Communities L 213: 13 (entered into force 30 July 1998)

45. Howard Florey/Relaxin, Case number V0008/94. Opposition Division of the European Patent Office; 8 December 1994. [1995] EPOR 541

46. Allen RH, Stabler SP and Lindenbaum J. Assay for sulfhydryl amino acids and methods for detecting and distinguishing cobalamin and folic acid deficiency. US4940658 (1990)

47. Klein RD and Mahoney MJ. Labcorp v Metabolite Laboratories: the Supreme Court listens, but declines to speak. Journal of Law, Medicine \& Ethics 2008; 36: 141-149

48. Laboratory Corp of America v Metabolite Laboratories, Inc, 126 SCt 543 (2005)

49. Metabolite Laboratories, Inc v Laboratory Corp of America, No.99-Z-870 (District of Colorado, November 21 2001)

50. Metabolite Laboratories, Inc v Laboratory Corp of America, 370 F3d 1354 (Fed Cir, 2004)

51. *Cho MK, Illangasekare S, Weaver MA, Leonard DG and Merz JF. Effect of patents and licenses on the provision of clinical genetic testing services. Journal of Molecular Diagnostics 2003; 5: 3-8 
This article was the first to show that enforcement of gene patents in the molecular diagnostic landscape was more prevalent than previously anticipated.

52. Paradise J. European Opposition to Exclusive Control Over Predictive Breast Cancer Testing and the Inherent Implications for United States Patent Law and Public Policy: A Case Study of the Myriad Genetics' BRCA Patent Controversy. Food \& Drug Law Journal 2004; 59:133-154

53. Pressman L, Burgess R, Cook-Deegan RM, et al. The licensing of DNA patents by US academic institutions: an empirical study. Nature Biotechnology 2006; 24: 31-39

54. Mikhail P. Hopkins v CellPro: an illustration that patenting and exclusive licensing of fundamental science is not always in the public interest. Harvard Journal of Law and Technology 2000; 13: 375-394

55. **Walsh JP, Arora A and Cohen WM. Effects of research tool patenting and licensing on biomedical innovation. In Cohen WM and Merrill SA (eds). Patents in the knowledge-based economy. Washington: National Academies Press, 2003: 285-340 This research provides important empirical evidence of the strategies that the biomedical industry has adopted to deal with gene and related patents.

56. Nicol D. Balancing innovation and access to healthcare through the patent system - an Australian perspective. Community Genetics 2005; 8: 228-234

57. Genetic Technologies Limited. Company announcements: licensing update. 15 January 2008. Available at:

http://www.gtg.com.au/index.asp?menuid=060.070.130\&artid=10722\&function=NewsA rticle [Last accessed 3 March 2008] 
58. Genetic Technologies Limited. Issued licences. Available at:

http://www.gtg.com.au/index.asp?menuid=060.070.190.020 [Last accessed 3 March 2008]

59. Ozdemir V, Williams-Jones B, Glatt SJ, et al. Shifting emphasis from pharmacogenomics to theragnostics. Nature Biotechnology 2006; 24: 942-946

60. Merz JF, Kriss DG, Leonard DG and Cho MK. Diagnostic testing fails the test. Nature 2002; 415: 577-579

61. Nicol D and Nielsen J. Patents and medical biotechnology: an empirical analysis of issues facing the Australian industry. Hobart: Centre for Law and Genetics, 2003

62. Green A, Wee R and Henaghan B. Biotechnology Patents and the New Zealand Health and Research Sectors. Abstract, Alberta Civil Liberties Research Centre Conference, One Origin, One Race, One Earth Calgary, November 15-17 2007. Available at: http://www.aclrc.com/OneOrigin/index.htm [Last accessed 31 March 2008]

63. Stern S and Murray FE. Do formal intellectual property rights hinder the free flow of scientific knowledge? An empirical test of the anti-commons hypothesis. NBER Working Paper No. W11465 2005. Available at: http://ssrn.com/abstract=755701 [Last accessed 31 March 2008]

64. **Walsh JP, Cho C and Cohen W. View from the bench: patents and material transfers. Science 2005; 309: 2002-2003

This article reports the important finding that despite concerns about enforcement of patents against biomedical researchers, essentially they remain immune from patent enforcement actions. 
65. Walpole IR, Dawkins HJS, Sinden PD and O'Leary PC. Human gene patents: the possible impacts on genetic services healthcare. Medical Journal of Australia. 2003; 179: 203-205

66. *Barton JH. Emerging patent issues in genomic diagnostics. Nature Biotechnology 2006; 24: 939-941

John Barton is an eminent scholar in this field and his views are widely recognised as carrying considerable authority in the field.

67. Eisenberg RS. Why the gene patenting controversy persists. Academic Medicine 2002; 77: 1381-1387

68. National Research Council, Committee on Intellectual Property Rights in the Knowledge-based Economy. A patent system for the $21^{\text {st }}$ century. Merrill SA, Levin RC and Myers MB (eds). Washington, DC: National Academies Press, 2004

69. Australian Law Reform Commission. Genes and Ingenuity: Gene Patenting and Human Health. Report 99. Canberra: Australian Government, 2004

70. Canadian Biotechnology Advisory Council. Report: Human Genetic Materials, Intellectual Property and the Health Sector. Ottawa: Government of Canada, 2006

71. *Rimmer M. The Freedom to Tinker: Patent Law and Experimental Use. Expert Opinion on Therapeutic Patents 2005; 15: 167-200

This article provides a valuable overview of the law relating to experimental use in multiple jurisdictions.

72. De Francesco L. Genetic profiteering. Nature Biotechnology 2006; 24: 888-890

73. Romeo-Malanda S and Nicol D. Pharmacogenetic testing: legal considerations for consent, privacy, and disclosure. Personalized Medicine 2008; 5: 155-161 
74. Batchelder K and Miller P.A change in the market - investing in diagnostics. Nature Biotechnology 2006; 24: 922-926

75. Baker M. New-wave diagnostics. Nature Biotechnology 2006; 24: 931-939

76. Eisenberg RS. Genomic patents and product development incentives. In Knoppers BM, Laberge C and Hirtle M (eds). Human DNA: law and policy. The Hague: Kluwer Law International, 1997: 373-378

77. Shapiro C. Navigating the patent thicket: cross licences, patent pools and standardsetting. In Jaffe A, Lerner $\mathrm{J}$ and Stern $\mathrm{S}$ (eds.). Innovation policy and the economy. Cambridge, Mass: MIT Press, 2001; 119-150

78. **Heller MA and Eisenberg RS. Can patents deter innovation? The anticommons in biomedical research. Science 1998; 280: 698-702

This is the leading article on the theoretical concerns about the impact of patents in biomedicine.

79. Caulfield T, Cook-Deegan RM, Keiff FS and Walsh JP. Evidence and anecdotes: an analysis of human gene patenting controversies. Nature Biotechnology 2006; 24: 10911094

80. Intellectual Property Institute. Patents for genetic sequences: the competitiveness of current UK law and practice. London: Department of Trade and Industry, 2004

81. Organisation for Economic Co-operation and Development. Genetic inventions, intellectual property rights and licensing practices: evidence and policies. Berlin: OECD, 2002 
82. Caulfield BA. Why we hate gene patents. IP Worldwide. 30 December 2002.

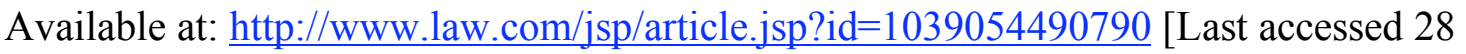

February 2008]

83. Organisation for Economic Cooperation and Development. Guidelines for the Licensing of Genetic Inventions. Paris: OECD, 2006

84. National Institutes of Health. Principles and guidelines for recipients of NIH research grants and contracts on obtaining and disseminating biomedical research resources: final notice. Federal Register 1999; 64: 72090

85. National Institutes of Health. Best practices for the licensing of genomic inventions: final notice. Federal Register 2005; 70: 18413

86. Clark J, Piccolo J, Stanton B and Tyson K. Patent pools: a solution to the problem of access in biotechnology patents? Washington: United States Patent and Trademark Office, 2000

87. Ebersole TJ, Guthrie MN and Goldstein JA. Patent pools and standard setting in diagnostic genetics. Nature Biotechnology 2005; 23: 937-938

88. Resnik DB. A biotechnology patent pool: an idea whose time has come? Journal of Philosophy, Science \& Law 2003, 3: January. Available at:

http://www6.miami.edu/ethics/jpsl/archives/papers/biotechPatent.html [Last accessed 31 March 2008]

89. **Van Overwalle G, van Zimmern E, Verbeure B and Matthijs G. Models for Facilitating Access to Patents on Genetic Inventions. Nature Review Genetics 2006, 7: $143-148$

This article provides an excellent overview of the various options for cooperative licensing in biomedicine. 
90. Verbeure B, van Zimmeren E, Matthijs G and van Overwalle G. Patent pools and diagnostic testing. Trends in Biotechnology 2006; 24: 115-120

91. Krattiger A, Kowalski S, Eiss R and Taubman A. Intellectual property management strategies to accelerate the development and access of vaccines and diagnostics: case studies on pandemic influenza, malaria and SARS. Innovation Strategy Today 2006; 2: $67-122$

92. Gaulé P. Towards patent pools in biotechnology? Innovation Strategy Today 2006; 2: $123-134$

93. Graff $G$ and Zilberman D. Towards an intellectual property clearinghouse for agricultural biotechnology. Intellectual Property Strategy Today 2001; 3: 1-14

94. Van Zimmeren E, Verbeure B, van Overwalle G and Matthijs G. A clearing house for diagnostic testing: the solution to ensure access to and use of patented genetic inventions? Bulletin of the World Health Organisation 2006; 84: 352-359

95. Hope J. Biobazaar: the open source revolution and biotechnology. Cambridge, Mass: Harvard University Press, 2008

96. Nicol D and Hope J. Cooperative strategies for facilitating use of patented inventions in biotechnology. Law in Context 2006; 24: 85-112

97. Aymé S, Matthijs G and Soni S on behalf of the ESHG Working Party on Human Genetics. Patenting and licensing in genetic testing: recommendations of the European Society of Human Genetics. European Journal of Human Genetics 2008; 16: 405-411 